\title{
Fatty acids and sugar composition of avocado fruit during harvesting time and post-harvest ripening period: a review
}

\author{
Vittorio Farina $^{1^{*}}$, Carmina Reig ${ }^{2}$ \\ ${ }^{1}$ Department of Agricultural, Food and Forest Sciences, University of Palermo, Italy \\ ${ }^{2}$ Instituto Agroforestal Mediterráneo, Universitat Politècnica de València, Spain
}

Ricezione: 15 giugno 2018; Accettazione: 30 giugno 2018

\section{Metabolismo dei lipidi e composizio- ne zuccherina in frutti di Avocado in pre e postraccolta}

Riassunto. Nello studio della maturazione dell'avocado il metabolismo dei lipidi in pre e postraccolta assume un ruolo fondamentale poiché la parte edibile del frutto è caratterizzata quasi esclusivamente dall'accumulo di grassi. Occorre comprendere anche le variazioni nella composizione zuccherina poiché la formazione degli acidi grassi è legata al glicerolo, un prodotto del metabolismo degli zuccheri.

Parole chiave: Avocado, persea americana, acidi grassi, zuccheri, lipidi, carboidrati, maturazione

\section{Introduction}

Avocado (Persea Americana Mill) is mainly grown in Mexico, USA and Indonesia (Anon., 2000). However, the cultivation of avocado is expanding into some non-traditional localities, such as Sicily and Calabria in the Mediterranean area (Ozdemir \& Topuz 2004). The avocado is a berry fruit with a dark green leathery skin and a very large seed. Avocado is an unusual fruit in that it can be held on the tree for very long periods after reaching physiological maturity. In fact, fruits are picked when they are mature but unripe and, therefore, have the advantage of being left on the tree during the season and harvested repeatedly. In some environments, fruit can be held on the tree for one year or more after physiological maturity.

From a nutritional point of view, avocado is an important and high caloric fruit and is relatively rich in certain vitamins, dietary fiber, minerals, and nitrogenous substances (tab. 1). Avocado fruit is used as a high energy food source for its high content of

\footnotetext{
*vittorio.farina@unipa.it
}

lipids (Mazliak, 1965; Mazliak, 1961; Tango et al., 1972; Gaydou et al, 1978). The mesocarp tissue of the fruit is composed of $72 \mathrm{~g} / 100 \mathrm{~g}$ water, $15.4 \mathrm{~g} / 100 \mathrm{~g}$ total lipids, $1.96 \mathrm{~g} / 100 \mathrm{~g}$ protein, $6.8 \mathrm{~g} / 100 \mathrm{~g}$ fiber, total sugars $0.3 \mathrm{~g} / 100 \mathrm{~g}, 8.64 \mathrm{~g} / 100 \mathrm{~g}$ carbohydrates, $1.66 \mathrm{~g} / 100 \mathrm{~g}$ ash, besides the presence of almost all important vitamins and minerals (Dreher and Davenport, 2013). Indeed its high content of fatty acids is one of its distinguishing characteristics. In particular, avocado mesocarp tissue has inherently high concentrations of unsaturated fatty acids and seven-carbon (C7) carbohydrates. Several studies (Colquhoun et al., 1992; Alvizouri-Munoz et al., 1992; Lerman-Garber et al., 1994; Carranza et al., 1995; Lopez-Ledesma et al., 1996; CarranzaMadrigal et al., 1997; Dreher \&Davemport, 2013) suggest that avocado enriched diets have a positive effect on blood lipids compared to low-fat, high carbohydrate diets. High dietary intake of these fatty acids has been related to a decreased risk of cardiovascular disease (Lopez-Ledesma et al., 1996; Mendez and Hernandez, 2007) and seem to have positive effects on weight control (Bes-Rastrollo et al., 2008). Research has shown that diets rich in avocado fruit may contribute to lowering cholesterol levels (Grant, 1960; Ledesma et al., 1996). DMannoheptulose (Board et al., 1995) and its reduced form polyol, perseitol (Ishizu et al., 1992), have been reported to have anticancer activity.

In addition, avocados are a rich source of bioactive phytochemicals such as vitamin E, some carotenoids, vitamin $\mathrm{C}$, phenols, and sterols (mainly $\beta$-sitosterol), among others (Ding et al., 2007; Lu et al., 2005) which have been shown to possess antioxidant and radical scavenging activities. Avocado fruit has been found to be a good source of phytosterols in respect to other fruits (tab. 2) (Piironen et al., 2003). $\beta$-Sitosterol is the main phytosterol found in fruits, and its proportion ranges between $72 \%$ and $86 \%$ (Piironen et al., 2003). 


\section{Farina e Reig}

Tab. 1 - Nutritional profile of US-grown avocados and avocado oil (per 100 g). Source: USDA in Dreher and Davenport (2013).

Tab. 1 - Profilo nutrizionale di frutti e olio di avocado raccolti negli USA (per 100 g). Fonte: USDA in Dreher e Davenport (2013).

\begin{tabular}{|c|c|c|c|c|}
\hline Nutrient/phytochemical & Value per $100 \mathrm{~g}$ & 1 fruit, $136 \mathrm{~g}$ & $\begin{array}{c}1 / 2 \text { fruit, } 68 \mathrm{~g} \\
\text { (NHANES cating occasion) }\end{array}$ & $\begin{array}{l}1 \text { serving, } 30 \mathrm{~g} \\
\text { (NLEA serving) }\end{array}$ \\
\hline \multicolumn{5}{|c|}{ Proximates } \\
\hline Water $(\mathrm{g})$ & 72.3 & 98.4 & 49.2 & 21.7 \\
\hline Energy (k cal) & 167 & 227 & 114 & 50 \\
\hline Energy (k cal) )insoluble fiber adjusted & 148 & 201 & 101 & 44 \\
\hline Protein $(\mathrm{g})$ & 1.96 & 2.67 & 1.34 & 0.59 \\
\hline Total lipid (fat) (g) & 15.4 & 21.0 & 10.5 & 4.62 \\
\hline Ash $(\mathrm{g})$ & 1.66 & 2.26 & 1.13 & 0.50 \\
\hline Carboydrate, by difference (g) & 8.64 & 11.8 & 5.90 & 2.59 \\
\hline Fiber, total dictary $(\mathrm{g})$ & 6.80 & 9.20 & 4.60 & 2.00 \\
\hline Sugars, total $(\mathrm{g})$ & 0.30 & 0.41 & 0.21 & 0.09 \\
\hline Starch $(\mathrm{g})$ & 0.11 & 0.15 & 0.08 & 0.03 \\
\hline \multicolumn{5}{|c|}{ Minerals } \\
\hline Calcium (mg) & 13.0 & 18.0 & 9.0 & 4.0 \\
\hline Iron (mg) & 0.61 & 0.83 & 0.42 & 0.18 \\
\hline Magnesium (mg) & 29.0 & 39.0 & 19.5 & 9.0 \\
\hline Phosphurus (mg) & 54.0 & 73.0 & 36.5 & 16.0 \\
\hline Potassium (mg) & 507 & 690 & 345 & 152 \\
\hline Sodium (mg) & 8.0 & 11.0 & 5.5 & 2.0 \\
\hline Zinc (mg) & 0.68 & 0.92 & 0.46 & 0.20 \\
\hline Copper (mg) & 0.17 & 0.23 & 0.12 & 0.05 \\
\hline Manganese (mg) & 0.15 & 0.20 & 0.10 & 0.05 \\
\hline Selenium $(\mu \mathrm{g})$ & 0.40 & 0.50 & 0.25 & 0.10 \\
\hline \multicolumn{5}{|c|}{ Vitamins and Phytochemical } \\
\hline Vitamin C (mg) & 8.80 & 12.0 & 6.0 & 2.60 \\
\hline Thiamin (mg) & 0.08 & 0.10 & 0.05 & 0.02 \\
\hline Riboflavin (mg) & 0.14 & 0.19 & 0.09 & 0.04 \\
\hline Niacin (mg) & 1.91 & 2.60 & 1.30 & 0.57 \\
\hline Pantothnic acid (mg) & 1.46 & 2.0 & 1.0 & 0.44 \\
\hline Vitamin B-6 (mg) & 0.29 & 0.39 & 0.19 & 0.09 \\
\hline Folate food $(\mu \mathrm{g})$ & 89.0 & 121 & 60.5 & 27.0 \\
\hline Choline total (mg) & 14.2 & 19.3 & 9.65 & 4.30 \\
\hline Betaine (mg) & 0.7 & 1.0 & 0.5 & 0.2 \\
\hline Vitamin B-12 & 0 & 0 & 0 & 0 \\
\hline Vitamin A ( $\mu \mathrm{g}$ RAE) & 7.0 & 10.0 & 5.0 & 2.0 \\
\hline$\beta$-Carotene $(\mu \mathrm{g})$ & 63.0 & 86.0 & 43.0 & 19.0 \\
\hline$\alpha$-Carotene $(\mu \mathrm{g})$ & 24.0 & 33.0 & 16.5 & 7.0 \\
\hline$\beta$-Cryptoxantin $(\mu \mathrm{g})$ & 27.0 & 37.0 & 18.5 & 8.0 \\
\hline Lutein + zeaxanthin $(\mu \mathrm{g})$ & 271 & 369 & 185 & 81 \\
\hline Vitamin H ( $\alpha$-tocopherol) (mg) & 1.97 & 2.68 & 1.34 & 0.59 \\
\hline$\beta$-tocopherol (mg) & 0.04 & 0.05 & 0.03 & 0.01 \\
\hline$\gamma$-tocopherol (mg) & 0.32 & 0.44 & 0.22 & 0.10 \\
\hline$\Delta$-tocopherol (mg) & 0.02 & 0.03 & 0.02 & 0.01 \\
\hline Vitamin $\mathrm{K}_{1}$ (phylloquinone) $(\mu \mathrm{g})$ & 21.0 & 28.6 & 14.3 & 6.30 \\
\hline
\end{tabular}


Tab. 1 - Nutritional profile of US-grown avocados and avocado oil (per $100 \mathrm{~g})$. Source: USDA in Dreher and Davenport (2013).

Tab. 1 - Profilo nutrizionale di frutti e olio di avocado raccolti negli USA (per $100 \mathrm{~g}$ ). Fonte: USDA in Dreher e Davenport (2013).

\begin{tabular}{|c|c|c|c|c|}
\hline Nutrient/phytochemical & Value per $100 \mathrm{~g}$ & 1 fruit, $136 \mathrm{~g}$ & $\begin{array}{c}1 / 2 \text { fruit, } 68 \mathrm{~g} \\
\text { (NHANES cating occasion) }\end{array}$ & $\begin{array}{l}1 \text { serving, } 30 \mathrm{~g} \\
\text { (NLEA serving) }\end{array}$ \\
\hline \multicolumn{5}{|c|}{ Lipids } \\
\hline Fatty acids (total saturated) (g) & 2.13 & 2.90 & 1.45 & 0.64 \\
\hline $16: 0(\mathrm{~g})$ & 2.08 & 2.82 & 1.41 & 0.62 \\
\hline Fatty acids (total monosaturated) & 9.80 & 13.3 & 6.65 & 2.94 \\
\hline $18: 1$ & 9.07 & 12.3 & 6.15 & 2.71 \\
\hline Fatty acids (total polyunsaturated) & 1.82 & 2.47 & 1.24 & 0.55 \\
\hline $18: 2(\mathrm{~g})$ & 1.67 & 2.28 & 1.14 & 0.50 \\
\hline 18.3 & 0.13 & 0.17 & 0.09 & 0.04 \\
\hline Cholesterol (mg) & 0 & 0 & 0 & 0 \\
\hline Sigmasterol (mg) & 2.0 & 3.0 & 1.5 & 1.0 \\
\hline Campesterol (mg) & 5.0 & 7.0 & 3.5 & 2.0 \\
\hline Betasitosterol (mg) & 76.0 & 103 & 51.5 & 23.0 \\
\hline
\end{tabular}

Tab. 2 - Plant sterol of some tropical and subtropical fruit. Source: Normen et al. (1999), Piironen et al. (2003) in Shaffer et al. (2012). Tab. 2 - Steroli vegetali in differenti frutti tropicale e subtropicali. Fonte: Normen et al. (1999), Piironen et al. (2003) in Shaffer et al. (2012).

\begin{tabular}{|c|c|c|c|c|}
\hline Fruit & Campesterol & Stigmasterol & Sitosterol & Total Phytosterols \\
\hline Avocado & 4.1 & 0.3 & 61.8 & 75.2 \\
\hline \multirow{2}{*}{ Banana } & 1.5 & 1.8 & 11 & 14 \\
\hline & 1.3 & 1.3 & 8.4 & 11.6 \\
\hline \multirow{2}{*}{ Grapefruit } & 2.5 & 1.0 & 15 & 18 \\
\hline & 1.4 & 0.2 & 14.3 & 20.0 \\
\hline Kiwi & 0.44 & 1.4 & 7.2 & 9.1 \\
\hline Lemon & 3.3 & 1.3 & 13 & 18 \\
\hline \multirow{2}{*}{ Orange } & 3.0 & 1.0 & 20 & 24 \\
\hline & 3.4 & 0.9 & 17 & 22.8 \\
\hline Passion fruit & 8.8 & 0.62 & 34 & 44 \\
\hline Pineapple & 3.8 & 0.44 & 11 & 17 \\
\hline Watermelon & 0.18 & 0.26 & 0.91 & 1.3 \\
\hline
\end{tabular}

Avocado fruit as a high-fat fruit, contains rare sugars of high carbon number, (Yahia 2009b). An edible portion of $100 \mathrm{~g}$ of avocado contains $2.1 \mathrm{~g}$ of saturated fatty acids, $8.9 \mathrm{~g}$ of monounsaturated fatty acids, and $1.8 \mathrm{~g}$ of polyunsaturated fatty acids (tab. 1). It is important to note that this fruit has a good balance of omega fatty acids 3, 6, and 9 (Ortiz et al., 2003). The proximate analysis of avocado fatty acids is presented in table 3 .

\section{Harvest}

Determining the commercial maturity of the avocado is difficult because the start of ripening is not accompanied by evident visible external changes, with the exception of Hass cultivar, whom late season fruit change skin colour from green to purple/black
(Cox et al., 2004). Plumbley et al. (1989) investigated the change in fruit growth rate to predict the earliest harvest date based on the assumption that growth rate would be minimal at maturity. However, this method was unreliable because of variability among cultivars and production locations.

Fruit maturity and picking time are determined according to only two external markers (colour and size), or by measuring oil content in the flesh (Werman and Neeman, 1987; Lee et al., 1983; Kaiser, 1994). Since it is highly correlated to the dry matter (DM) content of the fruit (98\%) (Ranney, 1991), it is frequently used as a maturity indicator and a quality evaluation parameter.

Oil content is the best harvest maturity index for avocado (Hofman et al., 2002). Even \% DM is used routinely as the maturity index in Australia, Israel, 
Tab. 3 - Typical fatty acid composition of oils from different fruits. Source: Salas et al., 2000.

Tab. 3 - Contenuto di acidi grassi in olii di frutti differenti. Fonte: Salas et al., 2000.

\begin{tabular}{|c|c|c|c|}
\hline \multirow{2}{*}{ Fatty acid } & \multicolumn{3}{|c|}{ Composition (\%) } \\
\cline { 2 - 4 } & Olive & Avocado & Palm \\
\hline $12: 0$ & nd & nd & $<0.1$ \\
\hline $14: 0$ & nd & nd & $0.9-1.1$ \\
\hline $16: 0$ & $10-18$ & $9-13$ & $43.1-45.3$ \\
\hline $16: 1$ & $0.7-2.4$ & $2.8-4.0$ & $0.7-0.3$ \\
\hline $18: 0$ & $2.3-2.5$ & $0.4-1.0$ & $4.0-4.8$ \\
\hline $18: 1$ & $57-78$ & $69-74$ & $38.4-40.8$ \\
\hline $18: 2$ & $7-19$ & $10-14$ & $9.4-11.1$ \\
\hline $18: 3$ & $0.6-0.8$ & $1-2$ & $0.1-0.4$ \\
\hline $20: 0$ & $0.4-0.5$ & $<0.1$ & $0.1-0.4$ \\
\hline $20: 1$ & $<0.3$ & nd & nd \\
\hline
\end{tabular}

New Zealand, Chile and the United States, while South Africa uses flesh moisture content (Swarts, 1978). Pectin methyl esterase (PME) activity decreased more rapidly after harvest in less mature, compared with more mature fruit (Zauberman and Schiffmann-Nadel, 1972). On this basis it was suggested that PME activity might be a maturity indicator, but also considered unsuitable as a maturity index for its large variability during different harvest seasons (Kaiser et al., 1995).

Fruit firmness has been used for many years as a measure of avocado ripeness. Fruit bounce firmness measurement and acoustic impulse transmission technologies are used to separate fruits, such as avocados and mangoes, based on their firmness.

Nuclear Magnetic Resonance (NMR) spectroscopy has potential for estimation of oil content (Chen et al., 1993), also for in-line maturity testing in the packhouse (Kim et al., 1999), with correlation coefficients (r) of up to 0.98 with oil content measured by soxhlet extraction and NMR (Barry et al., 1983).

\section{Ripening}

Avocado ripening is a process whereby physiological and physical changes take place which make fruit attractive and palatable for consumption (Bower and Cutting, 1988). The ripening process in avocado fruit is unusual, in that softening and most other ripening characteristics do not normally occur in fruit firmly attached to the tree, but are initiated only after harvest and completing within 5-7 days following harvest (Seymour \& Tucker, 1993). It seems that there is a flow of inhibitive components from the leaves to the fruit, preventing fruit from softening on the tree (Werman \& Neeman, 1987). The most obvious changes during ripening are softening, and in some cultivars, exocarp (skin, rind) colour change, but many physiological changes accompany the process. On a macro-level, the two major phenomena are the respiratory and ethylene climacterics (Biale and Young, 1971). The postharvest ripening process is related to the amount of surrounding and endogenous ethylene, which increase the respiration rate (Ornelas \& Yahia, 2004). Pesis et al. (1978) found a direct correlation between cellulase activity and softening, respiration, and ethylene production. Similarly, Awad (1977) found a strong correlation between the rapid increases in cellulase content after harvest, the climacteric rise in respiration, and softening of the avocado fruit, where edible softness occurred before maximum cellulase levels were reached. However, many structural and physiological changes, both catabolic and anabolic (Seymour and Tucker, 1993) also occur, which result in the final softening and organoleptic changes. These involve enzymatic and structural modifications, as well as production of volatiles (Obenland et al., 2012). Lipids accumulate during avocado fruit development and constitute ca. $70 \%$ of dry matter at maturity. Oil accumulates until harvest ranging between 9 and 14\% depending on cultivar, cultural practices and location. Structural lipids are part of the cell membrane (phospholipids and glycolipids) and storage lipids (triglycerides) are in the idioblasts (Requejo-Tapia, 1999).

\section{Lipids metabolism}

From morphological and physiological viewpoints of fruit development, the avocado fruit deviated from most investigated fruits in its method of development in that cell division remained an important factor in fruit growth as long as the fruit remained on the tree (Schroeder, 1953). Furthermore, a large droplet of reserve lipids was deposited in each indioblast, a large specialized type of cell found in the mesocarp tissue. Saturated, monounsaturated and polyunsaturated fatty acids represented about 9,76 , and $15 \%$, respectively of the total fatty acids quantified. The edible portion of the fruit is rich in oleic, palmitic, linoleic, and palmitoleic acids, whereas stearic acid is present only in trace amounts (Villa-Rodriguez, et al., 2011; Lu et al., 2009). Among fatty acids (tab. 3) only four acids (palmitic and palmitoleic acids with sixteen carbons and oleic and linoleic acids with eighteen carbons) represented more than $95 \%$ of the fatty acids in the fruits (Mazliak, 1965). Oleic acid was found to be the main fatty acid in 'Hass' avocado (tab. 4), representing around 67 to $70 \%$ of total fatty acids, whereas rela- 
Tab. 4 - Changes in the fatty acid content of Hass avocado mesocarp at four ripeness stages (mg/100 g FW). Source: Villa-Rodriguez et al., 2011.

Tab. 4 - Composizione acidica della polpa di frutti di avocado cv Hass in quattro distinti stadi di maturazione (mg/100 g PF). Fonte: Villa-Rodriguez et al., 2011

\begin{tabular}{|c|c|c|c|c|}
\hline \multirow{2}{*}{ Fatty acid } & \multicolumn{4}{|c|}{ Ripeness stage } \\
\cline { 2 - 5 } & RS1 & RS2 & RS3 & RS4 \\
\hline Tridecanoic (13:0) & nd & nd & nd & 0.284 \\
\hline Myristic (14:0) & trace & trace & $0.029 \pm 0.004^{\mathrm{b}}$ & $0.0675 \pm 0.005^{\mathrm{a}}$ \\
\hline Palmitic (16:0) & $28.23 \pm 2.25^{\mathrm{b}}$ & $24.33 \pm 2.31^{\mathrm{b}}$ & $29.43 \pm 1.55^{\mathrm{b}}$ & $44.81 \pm 3.19^{\mathrm{a}}$ \\
\hline Stearic (18:0) & $0.12 \pm 0.001^{\mathrm{c}}$ & $1.04 \pm 0.001^{\mathrm{b}}$ & $1.17 \pm 0.11^{\mathrm{b}}$ & $3.43 \pm 0.25^{\mathrm{a}}$ \\
\hline Total SFA & $28.35 \pm 2.251^{\mathrm{c}}$ & $25.37 \pm 2.32^{\mathrm{d}}$ & $30.62 \pm 1.66^{\mathrm{b}}$ & $48.3 \pm 3.44^{\mathrm{a}}$ \\
\hline Palmitomeic (16:1) & $9.58 \pm 0.30^{\mathrm{c}}$ & $9.03 \pm 0.98^{\mathrm{c}}$ & $12.71 \pm 0.58^{\mathrm{b}}$ & $14.66 \pm 0.43^{\mathrm{a}}$ \\
\hline Cis-10-heptadecenoic (17:1) & trace & $0.25 \pm 0.005^{\mathrm{c}}$ & $0.35 \pm 0.01^{\mathrm{b}}$ & $0.42 \pm 0.02^{\mathrm{a}}$ \\
\hline Oleic (18:1) & $299.46 \pm 11.31^{\mathrm{a}}$ & $187 \pm 17.47^{\mathrm{c}}$ & $242.26 \pm 4.9^{\mathrm{b}}$ & $297.76 \pm 12.36^{\mathrm{a}}$ \\
\hline Total MFA & $309.04 \pm 11.61^{\mathrm{b}}$ & $196.28 \pm 18.45^{\mathrm{d}}$ & $255.32 \pm 5.49^{\mathrm{c}}$ & $312.84 \pm 12.81^{\mathrm{a}}$ \\
\hline Cis-13,16-Docosadienoic (22:2) & nd & nd & trace & $1.69 \pm 0.02$ \\
\hline Linoleic (18:2) & $51.09 \pm 4.08^{\mathrm{a}}$ & $29.94 \pm 3.18^{\mathrm{b}}$ & $37.31 \pm 1.07^{\mathrm{b}}$ & $50.06 \pm 2.16^{\mathrm{a}}$ \\
\hline$\alpha$-Linolenic (18:3) & $13.95 \pm 0.23^{\mathrm{a}}$ & $10.70 \pm 0.29^{\mathrm{b}}$ & $6.81 \pm 0.75^{\mathrm{c}}$ & $11.53 \pm 0.20^{\mathrm{b}}$ \\
\hline Total PFA & $65.04 \pm 4.31^{\mathrm{a}}$ & $40.64 \pm 3.47^{\mathrm{d}}$ & $44.12 \pm 1.82^{\mathrm{c}}$ & $63.28 \pm 2.38^{\mathrm{b}}$ \\
\hline M/S ratio & $10.9^{\mathrm{a}}$ & $7.73^{\mathrm{c}}$ & $8.33^{\mathrm{b}}$ & $6.47^{\mathrm{d}}$ \\
\hline P/S ratio & $2.29^{\mathrm{a}}$ & $1.6^{\mathrm{b}}$ & $1.44^{\mathrm{c}}$ & $1.31^{\mathrm{d}}$ \\
\hline M+P/S ratio & $13.19^{\mathrm{a}}$ & $9.33^{\mathrm{b}}$ & $9.77^{\mathrm{b}}$ & $7.78^{\mathrm{c}}$ \\
\hline
\end{tabular}

Values are the mean of three indipendent determinations \pm standard error $(n=9)$. Different superscript letter in the same fatty acid indicate significant difference $(\mathrm{p}<0.05)$. SFA: saturated fatty acid; MFA: monosaturated fatty acid; PFA: polyunsaturated fatty acid; nd: not detected

tive contents of palmitic, linoleic, palmitoleic, and alpha-linolenic acids were $13.5,12.6,3.26$ and $1 \%$ of total fatty acids, respectively (Villa-Rodriguez, et al., 2011). Fatty acid composition varied in relation to changes in dry matter content and maturity stage (Ozdemir and Topuz, 2004; Villa-Rodriguez et al., 2011), growing conditions (Landahl et al., 2009; Donetti and Terry, 2014) and during postharvest ripening (Ozdemir and Topuz, 2004). In general, there was a significant increase in total content of monounsaturated and saturated fatty acids and a decrease of polyunsaturated fatty acids during the ripening period (tab. 4) (Villa-Rodriguez, et al., 2011; Lu et al., 2009). These changes have been related to the oxidative degradation of fatty acids (Richard et al., 2008). Davenport and Ellis (1959) indicated that the monoenoic acid was synthesized during a long period of fruit development, while the saturated and polyunsaturated fatty acids were synthesized only in the primary stage of growth. Moreover, Hulme (1971) noted that the proportion of oleic acid increases faster than the other fatty acids by retarding the harvest. Ozdemir \& Topuz (2004) noted that palmitic, palmitoleic, oleic and linoleic acids were found to be major fatty acids in oil of avocado Hass and Fuerte harvested from November to January. In January, stearic acid was not present for either variety, nor could linolenic acid be detected in the Hass variety. In general, oleic acid was the only fatty acid which increased continuously from November to January in both varieties whereas palmitic acid, in particular, showed a decrease (tab. 5).

The biosynthesis of triglyceride in avocado fruit was demonstrated by Barron and Stumpf in 1962. Microsomes isolated from avocado mesocarp appear to synthesize glycerides via a pathway essentially similar to the system in animal tissue. The route, called the Kennedy and Kornberg pathway proceeds from glycerophosphate to phosphatidic acid to diglycerides and finally to triglycerides (Salas et al., 2000). The lipid content of the avocado mesocarp increased during fruit development, whereas the content of water was reduced and its growth almost ceased before the fruit showed its maximum, accumulation of reserve lipid (Kikuta \& Erickson, 1968). During the phase of rapid lipid synthesis, oleic acid was predominantly synthesized, and eventually deposited as triglyceride in the mesocarp tissue of the fruit (Kikuta \& Erickson, 1968). The biochemistry of lipid metabolism in avocado has been recently reviewed (Salas $e t$ al., 2000). The all-important precursor for de novo fatty acid biosynthesis is acetyl-CoA. The necessary participation of a chloroplast acetyl-CoA carboxylase for the production of long chain fatty acids from [14C] acetate in avocado tissues has been assessed. 
Tab. 5 - Changes in the fatty acid content of Hass and Fuerte avocados oil at tree ripeness stages (mg/100 g FW). Source: Ozdemir and Topuz (2004).

Tab. 5 - Composizione acidica dell'olio di avocado Cv Hass e Fuerte in tre epoche di maturazione (mg/100 g PF). Fonte: Ozdemir e Tориz (2004).

\begin{tabular}{|c|c|c|c|c|}
\hline \multirow{2}{*}{ Fatty acids } & \multirow{2}{*}{ Cultivars } & \multicolumn{3}{|c|}{ Harvesting time } \\
\hline & & November & December & January \\
\hline \multirow{2}{*}{ Palmitic acid } & Fuerte & $22.4^{a} \pm 0.693$ & $17.7^{b} \pm 0.600$ & $12.0^{c} \pm 0.740$ \\
\hline & Hass & $23.3^{a} \pm 0.256$ & $21.2^{b} \pm 0.245$ & $16.8^{c} \pm 0.508$ \\
\hline \multirow{2}{*}{ Palmitoleic acid } & Fuerte & $6.17^{a} \pm 0.296$ & $6.49^{a} \pm 0.298$ & $4.22^{b} \pm 0.409$ \\
\hline & Hass & $11.2^{\mathrm{a}} \pm 0.102$ & $10.6^{\mathrm{b}} \pm 0.158$ & $9.44 \pm 0.207$ \\
\hline \multirow{2}{*}{ Stearic acid } & Fuerte & $0.32^{\mathrm{a}} \pm 0.083$ & $0.12^{\mathrm{b}} \pm 0.058$ & $\mathrm{nd}^{\mathrm{c}}$ \\
\hline & Hass & $0.38^{a} \pm 0.053$ & $0.09^{\mathrm{b}} \pm 0.037$ & $\mathrm{nd}^{\mathrm{c}}$ \\
\hline \multirow{2}{*}{ Oleic acid } & Fuerte & $59.3^{c} \pm 0.396$ & $63.4^{\mathrm{b}} \pm 0.926$ & $73.0^{\mathrm{a}} \pm 0.999$ \\
\hline & Hass & $47.2 \pm 0.181$ & $52.1^{\mathrm{b}} \pm 0.321$ & $59.5^{\mathrm{a}} \pm 0.313$ \\
\hline \multirow{2}{*}{ Linoleic acid } & Fuerte & $10.3^{\mathrm{b}} \pm 0.761$ & $11.5^{\mathrm{a}} \pm 0.286$ & $10.5^{b} \pm 0.390$ \\
\hline & Hass & $16.1^{a} \pm 0.229$ & $15.0^{\mathrm{b}} \pm 0.167$ & $13.9^{c} \pm 0.400$ \\
\hline \multirow{2}{*}{ Linolenic acid } & Fuerte & $0.17^{a} \pm 0.073$ & $0.03^{b} \pm 0.014$ & $0.02^{b} \pm 0.024$ \\
\hline & Hass & $0.44^{\mathrm{a}} \pm 0.084$ & $0.09^{b} \pm 0.042$ & $\mathrm{nd}^{\mathrm{c}}$ \\
\hline \multirow{2}{*}{ Arachidic acid } & Fuerte & $0.33^{b} \pm 0.063$ & $0.53^{a} \pm 0.059$ & $0.24^{b} \pm 0.045$ \\
\hline & Hass & $0.98^{a} \pm 0.042$ & $0.81^{\mathrm{b}} \pm 0.030$ & $0.41^{\mathrm{c}} \pm 0.027$ \\
\hline
\end{tabular}

The means followed by the different superscript letters in the same line are significantly different ( $\mathrm{p}<0.05$ Duncan's multiple range test); nd: not detected

The products of fatty acid syntheses are mainly C16 or C18 saturated acyl chains. The fatty acid composition of the lipids of avocado fruit and avocado oil differs greatly with cultivar, stage of ripening, anatomical region of the fruit, and geographic location (Kikuta et al., 1968; Itoh and others 1975; Lu et al., 2005, Landahl et al., 2009). Ferreyra et al (2016) studied that the contents of oleic, palmitic, and palmitoleic acids were influenced by climatic and nutritional factors: in localities with lower temperatures, the 18-carbon fatty acid content increased, and the 16carbon fatty acid content decreased (tab. 6). A higher proportion of monounsaturated to saturated fatty acids in avocados grown in cooler climates (Requejo-Tapia, 1999) have been related to a mechanism to confer more fluidity to the membranes (Catala, 2009). The fatty acid profile is the result of the adaptation to the environment (Blakey, 2011) and even they have recently been proposed as potential biomarkers to distinguish avocado fruit growing areas (Donetti and Terry, 2014).

However, after harvest, the oil content and the fatty acid composition of the oil change differently with the avocado varieties, harvesting time and postharvest ripening period (Pederschi et al., 2015; Ozdemir and Topuz, 2004). The oleic acid did not change within 8 days of shelf life, whereas palmitic generally decrease and linolenic increase. Changes in classes of avocado lipids were observed during stor- age (Luza et al., 1990). There were reductions in the rate of triglyceride synthesis and diglyceride content as well as marked increases in monoglyceride and free fatty acid fractions, suggesting that lipids were involved to some extent in metabolic changes during the ripening process. In particular, the saturated fatty acids and the polyunsaturated fatty acids tended to increase (Davemport \& Ellis, 1959). The fatty acid composition did not change significantly during 2, 4 and 6 weeks storage at $0^{\circ}, 5^{\circ}$ and $10^{\circ} \mathrm{C}$ or after ripening at $20^{\circ} \mathrm{C}$ subsequent to the cold storage treatments (Eaks, 1990) Minimal change in the fatty acid composition has been reported during postharvest. The increased oil concentration reported during storage and ripening were related to postharvest dehydration and the increased oil concentration during ripening was attributed to increased lipid recovery due to partial cell wall breakdown (Mostert et al., 2007; Meyer and Terry, 2008).

\section{Oil content and dry matter}

Oil content is a very desirable attribute for avocados. Its concentration of avocado fruit increases during fruit development and is a significant determinant of eating quality (Meyer and Terry, 2008). This increase, as well, is possibly due to the action of cell wall degrading enzymes causing the oil to be liberated from the cellular bodies (idioblastic), making it more 


\begin{tabular}{|c|c|c|c|c|c|}
\hline$\stackrel{\infty}{\mathrm{d}} \widehat{\varrho}$ & 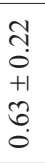 & $\begin{array}{l}0 \\
0 \\
0 \\
+1 \\
\infty \\
+0 \\
0\end{array}$ & $\begin{array}{l}\infty \\
0 \\
0 \\
0 \\
+1 \\
0 \\
0 \\
0\end{array}$ & $\begin{array}{l}0 \\
\overrightarrow{0} \\
+1 \\
0 \\
0 \\
0\end{array}$ & \begin{tabular}{l} 
\pm \\
\multirow{0}{0}{} \\
+1 \\
0 \\
0 \\
0
\end{tabular} \\
\hline$\overline{\mathrm{J}} \mathrm{\varrho}$ & $\begin{array}{l}= \\
0 \\
+ \\
+1 \\
I \\
0\end{array}$ & $\begin{array}{l}n \\
0 \\
0 \\
+1 \\
n \\
0 \\
0 \\
0\end{array}$ & $\begin{array}{l}\infty \\
0 \\
0 \\
+1 \\
0 \\
0 \\
0\end{array}$ & $\begin{array}{l}t \\
0 \\
0 \\
+1 \\
0 \\
0 \\
0 \\
0\end{array}$ & $\begin{array}{l}\stackrel{0}{0} \\
0 \\
+1 \\
+1 \\
0 \\
0\end{array}$ \\
\hline $\bar{b} \stackrel{0}{d}$ & 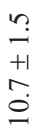 & $\begin{array}{l}n \\
o \\
+1 \\
\tilde{n} \\
0\end{array}$ & 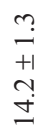 & $\begin{array}{l}3 \\
\underset{1}{+} \\
+1 \\
0 \\
\stackrel{0}{0}\end{array}$ & $\begin{array}{l}n \\
\stackrel{n}{+1} \\
\text { I } \\
\text { I }\end{array}$ \\
\hline 总 & $\begin{array}{l}\stackrel{0}{.} \\
\stackrel{+}{+1} \\
\stackrel{+}{\Xi} \\
\end{array}$ & $\begin{array}{l}0 \\
\stackrel{0}{+} \\
+1 \\
\stackrel{1}{0} \\
\stackrel{0}{=}\end{array}$ & $\begin{array}{l}\stackrel{+}{+} \\
\stackrel{+1}{\sim} \\
\stackrel{+}{ \pm}\end{array}$ & $\begin{array}{l}\stackrel{+}{\text { i }} \\
+1 \\
\stackrel{2}{I} \\
=\end{array}$ & $\begin{array}{l}\stackrel{0}{i} \\
+1 \\
\stackrel{a}{+} \\
\dot{I}\end{array}$ \\
\hline 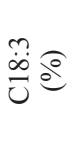 & 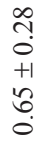 & $\begin{array}{l}n \\
n \\
0 \\
+1 \\
8 \\
0 \\
0\end{array}$ & $\begin{array}{l}n \\
n \\
0 \\
0 \\
+1 \\
0 \\
0 \\
0\end{array}$ & $\begin{array}{l}\overrightarrow{3} \\
0 \\
+1 \\
\tilde{b} \\
0\end{array}$ & $\begin{array}{l}\infty \\
\stackrel{\infty}{+}+0 \\
0 \\
+1 \\
\stackrel{0}{0}\end{array}$ \\
\hline ปิ่อ & $\begin{array}{l}\stackrel{0}{0} \\
0 \\
+1 \\
\text { İ } \\
0\end{array}$ & $\begin{array}{l}= \\
\vdots \\
0 \\
+1 \\
0 \\
0\end{array}$ & $\begin{array}{l}= \\
= \\
0 \\
+1 \\
\stackrel{+}{0} \\
0\end{array}$ & $\begin{array}{l}n \\
0 \\
0 \\
+1 \\
n \\
0 \\
0\end{array}$ & $\begin{array}{l}\stackrel{\circ}{\circ} \\
\stackrel{+}{+1} \\
\stackrel{0}{0} \\
\stackrel{0}{\circ}\end{array}$ \\
\hline$\underset{\dot{\theta}}{\tilde{u}} \stackrel{\varrho}{\varrho}$ & $\begin{array}{l}0 \\
\dot{0} \\
+1 \\
\stackrel{1}{a}\end{array}$ & 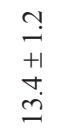 & $\begin{array}{l}0 \\
\dot{0} \\
+1 \\
m \\
m \\
\end{array}$ & $\begin{array}{l}\stackrel{0}{i} \\
+1 \\
\stackrel{1}{0} \\
\stackrel{0}{\leftrightarrows}\end{array}$ & $\begin{array}{l}\stackrel{+}{ \pm} \\
\stackrel{+1}{+} \\
\stackrel{ \pm}{\Xi}\end{array}$ \\
\hline 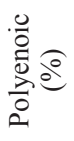 & $\begin{array}{l}\infty \\
\stackrel{0}{0} \\
+1 \\
\stackrel{0}{0} \\
\stackrel{0}{0}\end{array}$ & $\begin{array}{l}\text { I } \\
+1 \\
+1 \\
+ \\
\dot{J}\end{array}$ & $\begin{array}{l}+ \\
\dot{0} \\
+1 \\
\stackrel{-}{g} \\
\dot{\theta}\end{array}$ & $\begin{array}{l}\stackrel{+}{i} \\
+1 \\
\stackrel{े}{O} \\
\stackrel{-}{=}\end{array}$ & $\begin{array}{l}\stackrel{0}{i} \\
+1 \\
\stackrel{i}{I} \\
\text { In }\end{array}$ \\
\hline $\overrightarrow{0}$ & $\begin{array}{l}n \\
\stackrel{2}{0} \\
+1 \\
\stackrel{2}{0} \\
\stackrel{0}{0}\end{array}$ & $\begin{array}{l}\hat{n} \\
0 \\
0 \\
+1 \\
\vdots \\
0 \\
0\end{array}$ & $\begin{array}{l}n \\
n \\
o \\
+1 \\
? \\
0 \\
0\end{array}$ & $\begin{array}{l} \pm \\
\pm \\
0 \\
+1 \\
0 \\
0 \\
0\end{array}$ & $\begin{array}{l}n \\
\stackrel{0}{0} \\
+1 \\
\stackrel{1}{0} \\
0\end{array}$ \\
\hline 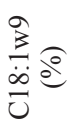 & 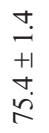 & $\begin{array}{l}\stackrel{n}{+1} \\
\stackrel{+1}{7} \\
\vec{\pi}\end{array}$ & 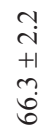 & $\begin{array}{l}0 \\
i \\
+1 \\
0 \\
0 \\
0 \\
0\end{array}$ & $\begin{array}{l}\infty \\
0 \\
+1 \\
0 \\
0 \\
0 \\
0\end{array}$ \\
\hline 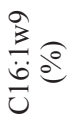 & 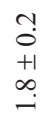 & 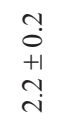 & $\begin{array}{l}\stackrel{+}{0} \\
+1 \\
+ \\
+\end{array}$ & $\begin{array}{l}m \\
\stackrel{?}{+} \\
\stackrel{+}{+}\end{array}$ & $\begin{array}{l}\stackrel{\sim}{I} \\
+1 \\
\stackrel{+}{+}\end{array}$ \\
\hline 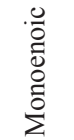 & 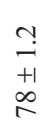 & $\begin{array}{l}9 \\
\stackrel{9}{+} \\
\stackrel{1}{2}\end{array}$ & $\begin{array}{l}\stackrel{0}{i} \\
\stackrel{+1}{R}\end{array}$ & $\frac{a}{+1}$ & $\begin{array}{l}\stackrel{+}{1} \\
+ \\
\text { i }\end{array}$ \\
\hline $\begin{array}{l}\text { : } \\
\stackrel{0}{0}\end{array}$ & נo & 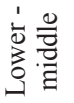 & $\frac{0}{\frac{0}{g}}$ & 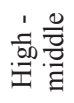 & $\begin{array}{l}\text {.5 } \\
.00 \\
.07\end{array}$ \\
\hline
\end{tabular}

available for extraction (Platt and Thomson, 1992). The minimum oil content necessary for marketing avocado fruit is $8 \%$. After maturation, values greater than $20 \%$ can occur. However, minimum values required for every market can largely vary, even for the same cultivar. Oil content increases in the mesocarp a few weeks after the fruit sets and can be correlated, afterwards, with the age of fruit. As oil increases in the mesocarp, water content decreases by the same amount, so that the total percentage of oil and water remains constant during fruit life (Ozdemir \& Topuz, 2004).

Percentage dry matter $(\% \mathrm{DM})$ is strongly related to oil content and quality (Lee et al., 1983; Brown, 1984; Ranney, 1991). The oil content and \% DM of 'Hass' showed a remarkably strong correlation (fig. 1), particularly given the wide diversity of rainfall, soil types and climates (Hofman et al., 2008a; Chen et al., 2009; Woolf et al., 2009). Generally, the oil content is about 11 units less than \% DM (e.g. 20\% total oil content equates to about $31 \% \mathrm{DM}$ ). Legal \% DM maturity indices in several countries were summarized by Hofman et al. (2002). For avocados, oil content and dry matter content increase as the fruit ripens. However, minimum values required for every market can largely vary, even for the same cultivar. For instance, Hass avocados require minimum values of $20.8 \%, 19.4 \%$, and $26.2 \%$ dry matter for fruits commercialized in California, Costa Rica, and Chile, respectively (Olaeta and Undurraga, 1995; Cerdas et al., 2006; Kader and Arpaia, 2010). In some countries, one standard is used for several cultivars and production locations. However, cultivar, cultural practices, season and micro and macro environments can influence the relationship between fruit oil content, \% DM and fruit quality (Lahav and Kalmar,1977; Lee et al., 1983; Coggins, 1984; Krugeret al., 1995). For example, Stahl (1933) noted large differences in \% DM between two locations in Florida, and attributed the differences to high rainfall in one of the districts causing a decrease in \% DM. Thus, Coggins (1984) suggested that production location influences \% DM to such an extent that it is an unreliable predictor of the earliest acceptable harvest date. However, Ranney (1991) concluded that season and locality effects on \% DM were not significant in California. To overcome some of these influences, more specific maturity standards can be applied. In South Africa, export regulations require the \% DM of all cultivars to be $>20 \%$ to prevent uneven ripening and shrivelling, with the exception of 'Hass' and 'Ryan' (> 23\%), and 'Edranol' (25\%). Fruit from the cooler areas of KwaZulu-Natal reach higher oil con- 


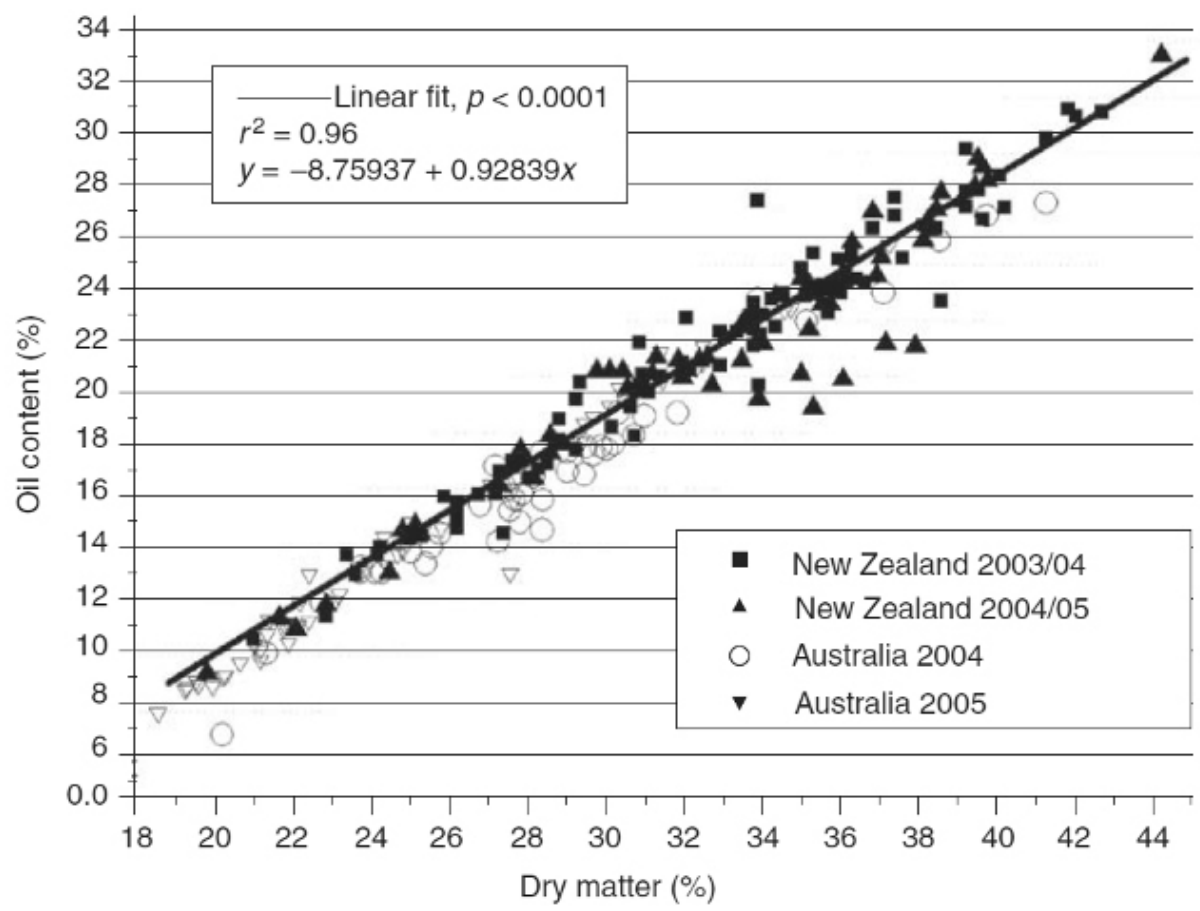

Fig. 1 - Relation between the percentage of dry matter and the oil content (percentage fresh weight basis) in the flesh of Hass avocado. Source: Schaffer et al, (2013).

Fig. 1 - Evoluzione del contenuto di olio e della percentuale di sostanza secca nella polpa dei frutti di avocado Cv Hass. Fonte: Schaffer et al, (2013).

centrations before other fruit maturity parameters are satisfied. Therefore, it is recommended that the fruit have a minimum DM of $25 \%$ ('Fuerte'), $28 \%$ ('Edranol') and 30\% ('Hass' and 'Ryan') for export (Kaiser and Wolstenholme, 1994). Fruit sampling procedures can also affect the accuracy of a maturity test. The \% DM can be affected by position in the canopy and flowering date (Plumbley et al., 1989; Vuthapanich, 2001), and by storage conditions between harvest and \% DM determination (Hofman and Jobin-Decor, 1999). Sampling of different size fruit and damaged fruit (Hofman and Jobin-Decor, 1999), and the portion of the flesh used (Schroeder, 1986) may also affect the \% DM result.

\section{Sugars}

Fruit growth is largely based upon transport of material from the photosynthesizing parts of the plant. The transport material is largely made up of sugars and sugar derivatives. These sugars are then metabolized in the fruit to the storage products, to cell structural materials and to provide energy for growing cells. Thus, even though the deposition of oil is a prominent feature of the growth of the avocado, formation of the fats depends on the breakdown of the carbohydrate material to acetate followed by synthesis of the fatty acids from the acetate. The fatty acids may then form fats by combining with glycerol, another sugar metabolism product. Further, the earlier studies of the change in composition of the avocado with growth (Church et al., 1922; Stahl, 1933; Dubois et al., 1956) have invariably shown a decrease in the amount of sugar storage in the pulp of the avocado while the oil content increased.

Compared to other fruits, avocados contain very little sugar (USDA, 2011). One-half an avocado contains only about 0.2 g sugar (e.g., sucrose, glucose, and fructose). The avocado mesocarp contains high concentrations of the $\mathrm{C} 7$ sugars, mannoheptulose and perseitol, while the C6 sugars fructose, glucose and sucrose are present in very low concentrations (Liu et al., 2002; Tesfay et al., 2010). The functions of these sugars are not fully understood, although D-mannoheptulose is the predominant anti-oxidant in avocado mesocarp (Tesfay et al., 2010), while perseitol is a storage compound (Tesfay, 2009) and is involved in micronutrient transport (Thorp et al., 2011). Other sugars (e.g., xylose) and sugar alcohols (mannitol or sorbitol) were also found in trace amounts (Bean, 1958). The primary sugar found in avocados is a unique seven-carbon sugar called D-mannoheptulose and its reduced form, perseitol, contributes about 2.0 g per one-half fruit (Meyer and Terry, 2008; Shaw et 
al., 1980). Preliminary D-mannoheptulose research suggests that it may support blood glucose control and weight management (Roth, 2009). In addition, the sugar alcohol perseitol possess anticancer activity (Board et al., 1995). The glycemic index and load of an avocado is expected to be about zero (Dreher \&Davemport, 2013).

The C7 sugar concentrations in the flesh was somewhat lower in immature fruit and again in very mature fruit, which may explain the changes in the incidence of internal disorders in fruit harvested at different stages of maturity. The seven carbon (C7) perseitol and mannoheptulose higher concentrations during ripening may reduce physiological flesh disorders (Meyer and Terry, 2010). The C7 sugar concentrations decrease significantly during ripening, possibly indicating a role in the ripening process (Liu et al., 2002). They may act as an energy source (Bertling et al., 2008; Meyer and Terry, 2010), and the double bond in mannoheptulose provides powerful water soluble anti-oxidant properties, which may be a first line of defence against the negative effects of reactive oxygen species (ROS) (Tesfay et al., 2010). Declines in the concentrations of D-mannoheptulose and perseitol, along with negligible concentrations of starch (Liu et al., 1999; Landahl et al., 2009), glucose, and fructose, suggest that the heptoses are used during the ripening process (Blakey 2012). Sugar concentrations in the flesh vary with maturity, and decreases in sugar concentrations may reduce energy reserves and quality of late harvested fruit (Bertling and Bower, 2005). However, perseitol concentrations varied inconsistently with harvest date over two seasons, while mannoheptulose concentrations declined in a consistent manner (Lallu et al., 2005; Burdon et al., 2007). This suggests that mannoheptulose may reflect a decline in fruit quality common in late-harvested fruit, but this needs to be confirmed. Soluble solids content, total sugars, sucrose, fructose and glucose do not vary consistently with harvest date (Lallu et al., 2005). Blakey (2012) observed a slight and inconsistent changes in the concentrations of sucrose during ripening, as found by Meyer and Terry (2010). These authors concluded that sucrose was not the primary carbon source or energy store in avocado fruit.

\section{Conclusions}

The study of the ripening process of avocado fruit is of great importance to generate information about the changes of individual fatty acids and to determine whether, there was a change in the quality of oil and fatty acid composition of avocado fruit during either the harvesting or the post-harvest ripening period. These evidence are important in providing information decide the proper harvesting time and storage practices.

\section{Abstract}

In a study of the maturity of avocado fruit it is important to elucidate the lipid metabolism in the fruit during growth and storage, since the avocado stores a large amount of lipids in the edible pulp. Meanwhile the fatty acids may then form fats by combining with glycerol, a sugar metabolism product, and sugar metabolism of the avocado fruit should be considered.

Key words: Avocado, persea americana, fatty acids, sugar, lipids, carbohydrates, ripening time

\section{References}

ANONYMOUS, 2000. FAO production yearbook. Rome.

Ahmed J., Lobo M.G., Ozadali F., 2012. Tropical and subtropical fruits: postharvest physiology, processing and packaging. John Wiley \& Sons.

Alvizouri-Munoz M., Carranza-Madrigal J., HerreraAbarca J.E., Chavez-Carbajal F., Amezcua-Gastelum J.L., 1992. Effects of avocado as a source of monounsaturated fatty acids on plasma lipid levels. Arch.Med. Res. 23: 163167.

AwAD M., 1977. Variation in cellulase content of Fuerte avocado fruit after harvest. Hort Sci 12: 406-8.

BARRY G.A., BRown B.I. BARKER L.R. 1983. The use of low resolution nuclear magnetic resonance for determining avocado maturity by oil content. Journal of Food Technology 18, 401410.

BEAN R.C., 1958. Changes in sugars during growth and storage of avocados. California Avocado Society Yearbook, 42, 90-93.

Bes-Rastrollo M., Van Dam R., Martinez-Gonzalez M., Li T., Sampson L., Hu F., 2008. Prospective study of dietary energy density and weight gain in women. American Journal of Clinical Nutrition 88, 769-777.

BLAKEY R., 2011. Management of avocado postharvest physiology. University of KwaZulu-Natal, Pietermartizburg, South Africa, pp. 1-180.

Blakey R.J., Tesfay S.Z., Bertling I., Bower J.P., 2012. Changes in sugars, total protein, and oil in 'Hass' avocado (Persea americana Mill.) fruit during ripening. The Journal of Horticultural Science and Biotechnology, 87:4, 381-387

Board M., Colquhoun A., Newsholme E., 1995. High Km glucose-phosphorylating(glucokinase) activities in a range of tumor cell lines and inhibition of rates oftumor growth by the specific enzyme inhibitor mannoheptulose. Cancer Research 55, 33278-33285.

Carranza J., Alvizouri M., Alvarado M.R., Chavez F., Gomez M., Herrera J.E., 1995. Effects of avocado on the level of blood lipids in patients with phenotype II and IV dyslipidemias. Arch. Inst. Cardiol. Mex. 65:342-8.

Carranza-Madrigal J., Herrera-Abarca J.E., AlvizouriMunoz M., Alvarado-Jimenez M.D.R., Chavez-Carbajal F., 1997. Effects of a vegetarian diet vs. a vegetarian diet enriched with avocado in hyper-cholesterolemic patients. Arch. Med. Res. 28(4):537-41 
CATAla A., 2009. Lipid peroxidation of membrane phospholipids generates hydroxylalkenals and oxidized phospholipids active in physiological and/or pathological conditions. Chemistry and Physics of Lipids 157, 1-11.

Chen P., McCarthy M.J., Kauten R., Sarig Y., Han S. 1993. Maturity evaluation of avocados by NMR methods. Journal of Agricultural Engineering Research 55, 177-187.

Church C.G., Chace E. M., 1922. Some Changes in the Composition of California Avocados During Growth. U.S. Dept. Agr. Bull. 1073: 1-22.

Colquhoun D., Moores D., Somerset S.M., Humphries J.A., 1992. Comparison of the effects on lipoproteins and apolipoproteins of a diet high in monounsaturated fatty acids, enriched with avocado, and a high-carbohydrate diet. Am. J. Clin. Nutr. 56:671-677.

Cox K.A., McGhie T.K., White A., Woolf A.B., 2004. Skin colour and pigment changes during ripening of 'Hass' avocado fruit. Postharvest Biology and Technology, 31 (3): $287-$ 294

DavenPort J.B., Ellis. S.C., 1959. Chemical changes during growth and storage of the avocado fruit. Aust. Jour. Biol. Sci. 12: 445-454.

Ding H., Chin Y.W., Kinghorn A.D., D’Ambrosio S.M., 2007. Chemopreventive characteristics of avocado fruit. Semin. Cancer Biol., 17, 386-394.

Donetti M., Terry L., 2014. Biochemical markers defining growing area and ripeningstorage of imported avocado fruit cv. Hass. Journal of Food Composition and Analysis 34, 9098.

Dreher M., DAvenPort A., 2013. Hass avocado composition and potential health effects. Critical Reviews in Food Science and Nutrition 53, 738-750.

Dubois M., Gillies K.A., Hamilton J.K., Rebers P.A., Sмiтн F., 1956. Colorimetric Method for Determination of Sugars. Anal. Chem., 28: 350-356.

EAKS I.R.V.I.N.G. .L., 1990. Change in the fatty acid composition of avocado fruit during ontogeny, cold storage and ripening. Acta Hortic. 269, 141-152

Ferreyra R., Sellés G., SaAvedra J., Ortiz J., Zúñiga C., Troncoso C., DefilipPi B.G., 2016. Identification of pre-harvest factors that affect fatty acid profiles of avocado fruit (Persea americana Mill) cv. 'Hass' at harvest. South African Journal of Botany, 104, 15-20.

Gaydou E.M., Lozano Y., Ratovohery J., 1987. Triglyceride and fatty acid compositions in the mesocarp of Persea Americana during fruit development. Phytochem. 26, 15951597.

GRANT W.C., 1960. Influence of avocados on serum cholesterol. Proc. Soc.Exp. Biol. Med. 104:45-47.

Kaiser C., Wolstenholme B.N., Levin J., 1995. Towards improving maturity standards for 'Fuerte' avocado (Persea americana Mill.) fruit in a cool subtropical climate. In: Proceedings of the III World Avocado Congress, Tel Aviv, Israel, pp. 277-284

Kim S.M., Chen P., MCCARThy M.J., ZIon B., 1999. Fruit internal quality evaluation using on-line nuclear magnetic resonance sensors. Journal of Agricultural Engineering Research 74, 293-301.

KIKUTA Y., ERICKSON L.C., 1968. Seasonal changes of avocado lipids during fruit development and storage. California Avocado Society Yearbook, 52, 102-108.

Hofman P., Fuch Y., Milne D., 2002. Harvesting, packing, postharvest technology, transport and processing. In: Whiley, A., Schaffer, B., Wolstenholme, B. (Eds.), The avocado: botany, production and uses. CABI Publishing, Wallingford, pp. 363-391.

Ishizu T., Winarno H., Tsujino E., Morita T., Shibuya H., 2002. Indonesian medicinal plants. XXIV.1) Stereochemical structure of perseitol $3 \mathrm{~K}+$ complex isolated from the leaves of
Scurrula fusca (Loranthaceae). Chem. Pharm. Bull. 50, 489-492.

Landahl S., Meyer M., Terry L., 2009. Spatial and temporal analysis of textural and biochemical changes of imported avocado $c v$. Hass during fruit ripening. Journal of Agricultural and Food Chemistry 57, 7039-7047.

Lee S.K., Young R.E., Schiffman P.M., Coggins C.W., 1983. Maturity studies of avocado fruit based on picking dates and dry weight. J. Amer. Soc. Hort. Sci, 108(3), 390-394.

Ledesma R.L., Munari A.C.F., Dominguez B.C.H., Montalvo S.C., Luna M.H.H., JuArez C., Lira S.M., 1996. Monounsaturated fatty acid (avocado) rich diet for mild hypercholesterolemia. Arch. Med. Res. 27, 519-523.

Lerman-Garber I., ICHAZO-Cerro S., Zamora-GonZalez J., CArdoso-Saldana G., Posadas-Romero C., 1994. Effect of a high-monounsaturated fat diet enriched with avocado in NIDDM patients. Diabetes Care. 17:311-315.

Lopez-Ledesma R., Frati M., Hernandez B., 1996. Monounsaturated fatty acid (avocado) rich diet for mild hypercholesterolemia. Archives of Medical Research 27, 519-523.

Lu Q., Zhang Y., Wang Y., Wang D., Lee R., Gao K., 2009. California "Hass" avocado: Profiling of carotenoids, tocopherol, fatty acid, and fat content during maturation and from different growing areas. Journal of Agricultural and Food Chemistry, 57(21), 10,408-10,413.

Lu Q.Y., Arteaga J.R., Zhang Q., Huerta S., Go V.L.W., HEBER D., 2005. Inhibition of prostate cancer cell growth by an avocado extract: role of lipid-soluble bioactive substances. J. Nutr. Biochem. 16, 23-30.

Luza J., Lizana L., Masson L., 1990. Comparative lipids evolution during cold storage of three avocado cultivars. Acta Horticulturae 269, 153-160.

Mazliak, P. 1965. Les lipides de I'avocat. II. Variation de la composition en acides gras des lipides du pericarpe selon la compositionde l'atmosphere autor des fruits en maturation. Fruits 20: 117-120.

MazliaK P. 1971. Avocado lipid constituents. Fruits 26, 615- 623.

Mendez P., Hernandez G., 2007. HDL-C size and composition are modified in the rat by a diet supplementation with 'Hass' avocado. Archives of Cardiology Mexico 77, 17-24.

Meyer M., Terry L., 2008. Development of a rapid method for the sequential extraction and subsequent quantification of fatty acids and sugars from avocado mesocarp tissue. Journal of Agricultural and Food Chemistry 56, 7439-7445.

Mostert M., Botha B., Du Plessis L., DuOdu K., 2007. Effect of fruit ripeness andmethod of fruit drying on the extractability of avocado oil with hexane and supercritical carbon dioxide. Journal of the Science of Food and Agriculture 87, $2880-2885$.

ORNELAS J., YAHIA E.M., 2004. Effects of prestorage dry and humid hot air treatments on the quality, tryglicerides and tocopherol contents in 'Hass' avocado fruit. Journal of Food Quality, 27, 115-126.

Ortiz A, Dorantes L, Galindez J, Guzman R. 2003. Effect of different extraction methods on fatty acids, volatile compounds, physical and chemical properties of avocado (Persea americana Mill) oil. J Agric Food Chem 51: 1060-71.

Ozdemir, F., Topuz, A. 2004. Changes in dry matter, oil content and fatty acids composition of avocado during harvesting time and post-harvesting ripening period. Food Chemistry, 86(1), 79-83.

Paull R.E., Duarte O., 2011. Tropical fruits (Vol. 1). CABI.

Pedreschi R., Hollak S., Harkema H., Otma E., Robledo P., Westra, E., DefilipPi, B. G. 2016. Impact of postharvest ripening strategies on 'Hass' avocado fatty acid profiles. South African Journal of Botany, 103, 32-35.

Pesis E, Fuchs Y, Zauberman G. 1978. Cellulase activity and fruit softening in avocado. Plant Physiol 61: 416-19. 
Pitronen V, Toivo J, Puupponen-Pimi"a R, Lampi A-M. 2003. Plant sterols in vegetables, fruits and berries. J Sci Food Agric 83: 330-7.

Plumbley R.A., Jeger M.J., Carbon W. 1989. Optimal picking date of avocado in Dominica, West Indies, in relation to flowering, fruit growth and chilling. Tropical Agriculture (Trinidad) 66, 129-134.

REQUEJO-TAPIA L., 1999. International trends in fresh avocado and avocado oil production and seasonal variation of fatty acids in New Zealand grown cv. Hass. Massey University.

Richard D., Kefi K., Barbe U., Bausero P., Visioli F., 2008. Polyunsaturated fatty acids as antioxidants. Pharmacological Research, 57(6), 451-455

Rотн G. 2009. Mannoheptulose glycolytic inhibitor and novel calorie restriction mimetic. Experimental Biology. Abstract \# 553.1. New Orleans, LA.

Salas J. J., Sanchez J., Ramli U. S., Manaf A. M., Williams M., HARWOOD J. L. 2000. Biochemistry of lipid metabolism in olive and other oil fruits. Progress in Lipid Research, 39, 151-180.

Schaffer B.A., Wolstenholme B.N., Whiley A.W. (Eds.). 2013. The avocado: botany, production and uses. CABI.

Schroeder C.A., 1953. Growth and development of the Fuerte avocado fruit. Amer. Soc. Hort. Sci. 61: 103-109.

Shaw, P., Wilson, III, C. W., KNight, JR., R. J. 1980. High-performance liquid chromatographic analysis of D-manno-heptulose, perseitol, glucose, and fructose in avocado cultivars. J. Agric. Food Chem. 28:379-462.

Seymour, G. B., Tucker, G. A. 1993. Avocado. In G. B. Seymour, J. Tayler, \& G. A. Tucker (Eds.), Biochemistry of fruit ripening (pp. 53-81). London: Chapman \& Hall.

Stahl A.L., 1933. Changes in Composition of Florida Avocados in Relation to Maturity. U. of Fla., Agr. Exp. Sta., Bull. 259: $1-61$.

TAngo M., Da Costa S.I., Antunes A.J, Figueriedo I.B., 1972. Composition of fruit oil of different varieties of avocado grown in San Paulo. Fruits 27, 143-146.

TeSfay, S. Z. (2009). Special Carbohydrates of Avocado - Their Function as 'Sources of Energy' and 'Anti-oxidants'. Ph.D.Thesis, University of KwaZulu-Natal, Natal, Pietermaritzburg, South Africa. $182 \mathrm{pp}$.

Tesfay, S. Z., Bertling, I. And Bower, J. P. (2010). Anti-oxidant levels in various tissues during the maturation of 'Hass' avocado (Persea americana Mill.) Journal of Horticultural Science \& Biotechnology, 85, 106-112.

Thorp, T. G., Barnett, A. M., Boldingh, H., Elmsly, T. A. And Minchin, P. E. H., 2011. Is boron transport to avocado flowers regulated by carbohydrate supply? Proceedings of the $7^{\text {th }}$ World Avocado Congress. Cairns,Australia. 6 pp.

Villa-Rodriguez J.A., Molina-Corral F.J., Ayala-Zavala J. F., Olivas G. I., Gonzalez-Aguilar G. A., 2011. Effect of maturity stage on the content of fatty acids and antioxidant activity of 'Hass' avocado. Food Research International, 44(5), 1231-1237.

Werman M.J., Neeman, I., 1987. Avocado oil production and chemical characteristics. JAOCS, 64(2), 229-232.

Zauberman G., Schiffmann-Nadel M., 1972). Pectinmethylesterase and polygalacturonase in avocado fruit at various stages of development. Plant Physiology 49 , $864-865$. 
